\title{
Original Research Paper \\ Amel Gene Profiling from Toothbrush for Sex Determination \\ Among Tanzanians in Surabaya, East Java.
}

\author{
Simon Martin Manyanza Nzilibili a,b, M Sc. Forensic Science Student \\ Ahmad Yudianto ${ }^{\text {a,c,d, }}$, Lecturer \\ Forensic Science Program, Post Graduate School, Airlangga University, Surabaya - Indonesia. \\ Ministry of Health, Community Development, Gender Elderly and Children, Dodoma - Tanzania. \\ Department of Forensic and Medico-legal, Faculty of Medicine, Airlangga University, Surabaya - Indonesia \\ Human Genetic Laboratory, Institute of Tropical Disease, Airlangga University, Surabaya - Indonesia.
}

\section{ABSTRACT :}

Introduction : Forensic identification depends significantly on evidence detected at the crime scene. Toothbrush continues to prove its usability to aid the identification for sex determination. Its contributory power continues to be confirmed to the different population at the varied time.

Materials and Methods : The present study reports the use of toothbrush in determining sex through Amel gene method by DNA band contrast at 106bp and 112bp among Tanzanians on ten volunteers.

Results : Electrophoresis band contrast confirmed six samples to be of male origin and three sample for the female. One sample presented undetectable DNA band contrast by showing the blank image on F1 sample profiled.

Conclusion : Toothbrush as source of biological samples and Amelogenin gene through DNAband contrast analysis is helpful in sex determination among Tanzanians. This finding not only evidently proposes but also contributes to bench marking applicability of Amel gene analysis as a successful and reliable method of sex determination to localized population (Tanzanians) for strengthened evidential data for forensic service.

\section{Corresponding Author}

\section{Simon Martin Manyanza Nzilibili}

Forensic Science Program, Postgraduate School, Airlangga

University, 4-6 Airlangga Rd., 60286 Surabaya, Indonesia

Contact : +6281334326515

E-mail : nzilibili@gmail.com

\section{Article History:}

Received: 18 September 2018

Received in revised form: 18 November 2018

Accepted on: 18 November 2018

Available online: 1 June 2019

KEYWORDS : Amel Gene, Toothbrush Evidence, Sex Determination

\section{INTRODUCTION :}

Sex determination remains an essential parameter to the revelation of unknown live or dead ${ }^{[1]}$. Gene profile through DNA analysis has proved a reliable technique for this purpose ${ }^{[2]}$. Toothbrush like any other evidence that might be found at a crime scene, can help in identification of an individual by analysis of the harbored material ${ }^{[3-6]}$. This technique is based on Locard's exchange principle, that anything in violent contact may be retained or taken back and can later used as trace evidence $^{[7]}$. To attain sex determination of such recovered sample, a number of methods are studied one of which is through the use of Amel gene (categorized in a molecular group of methods) ${ }^{[8]}$. AMEL $\mathrm{X}$ gene (female sex-determining DNA chromosomal marker) is present in 106 bps (base pairs) and AMEL Y (male sex-determining DNA chromosomal marker) is present in 112bps of the DNA hence homologous (XX) in female and heterogonous allele in male. This gene form Amelogenin which become detected as protein when individualizing $\operatorname{sex}^{[8-9]}$. The method is widely accepted in forensic sex identification with a tolerable percentage error ${ }^{[10]}$. If the results are doubtful, it is suggested to runthe SRY gene (sex region gene on the Y chromosome that is necessary and sufficient for male sex determination) or/and Y-STR markers (specialized class of short tandem repeats on the male Y-chromosome often used in forensics, paternity, and genealogical DNA testing) as parallel methods in order to confirm and resolve ambiguity ${ }^{[11-12]}$. Despite the marginalized ambiguity, its usefulness remains profound into varied populations and continue to be suggested among techniques in sex determination ${ }^{[8,13,14]}$.

Social offenses, crime and disasters casualties accelerate immensely in costing and endangering global life among Tanzania inhabitants. Solving the mystery, forensic identification responds to involved individual, couple, family or mass in terroristic, catastrophic or destructive events. Forensic scientists at the front line are obliged to bring the 
meaning of all thought "evidence" in identification to sexing gender of the involved for the law-suit purpose or resolving trepidation of the grieving ${ }^{[15,16]}$. In mutilated, destructed, decomposed or burned cases, toothbrush substantiates DNA profile of genetic materials logged with cells worn during brushing. Therefore; this study aimed at exploring the usefulness of toothbrush and Amelogenin in determining sex among Tanzania population. This will mark continued efforts in deriving experience from a different population and strengthening and improving forensic services and human resource personnel in line with tremendous changes that Tanzania is taking recently ${ }^{[17]}$.

\section{MATERIALS AND METHODS :}

After taking approval from Ethics committee and consent from Ten Tanzanians (six male and four female) participants, the present study was conducted at the Human Genetic Laboratory of the Airlangga University. Toothbrushes were collected after being used (as instructed) regularly for one week and sent to the laboratory for DNA analysis.

\section{Experimentation Process :}

Analytical process started by soaking of the toothbrushes into distilled water for an overnight in order to recover the logged biological samples (worn cells) from bristles at room temperature. Recovered biological samples were extracted by an organic method using DNA zol (Invitrogen, Thermo Fisher Scientific, Waltham, MA, USA) at alternated Voltex, incubation and centrifugation ${ }^{[18-19]}$. Resulted pellet was resuspended to form $50 \mu \mathrm{l}$ final volume which was then measured by Ultraviolet-visible Spectrophotometer (UV1601, PC, Shimadzu, Japan) to obtain concentration and purity. Amplification of sex fragment was by PCR mix (Promega Corporation, Madison, USA) using common amelogenin gene (Promega Corporation, Madison, USA) at a set of (forward: 5'-CCCTGGGCTCTGTAAAGAA-3' and reverse: 5'-ATCAGAGCTTAAACTGGGAAGCTG-3') primers as recommended ${ }^{[20]}$.Amplified DNA of Amel genes (106bp and 112bp) were visualizedas band contrast using Gel Polyacrylamide 6\% gel (cat. K562, GoTaq ${ }^{\circledR}$, Green Master Mix, Promeg a Corp, Madis on, US A ) f o r m e d b y electrophoretic migration.

\section{A : DNA extraction process using DNAzol}

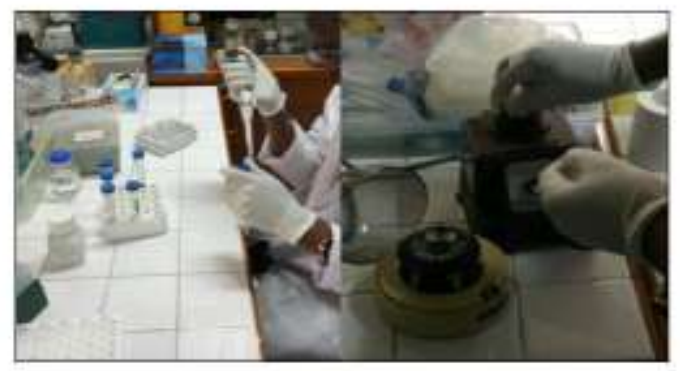

Spectrophotometer machine used to MEASURE extracted DNA

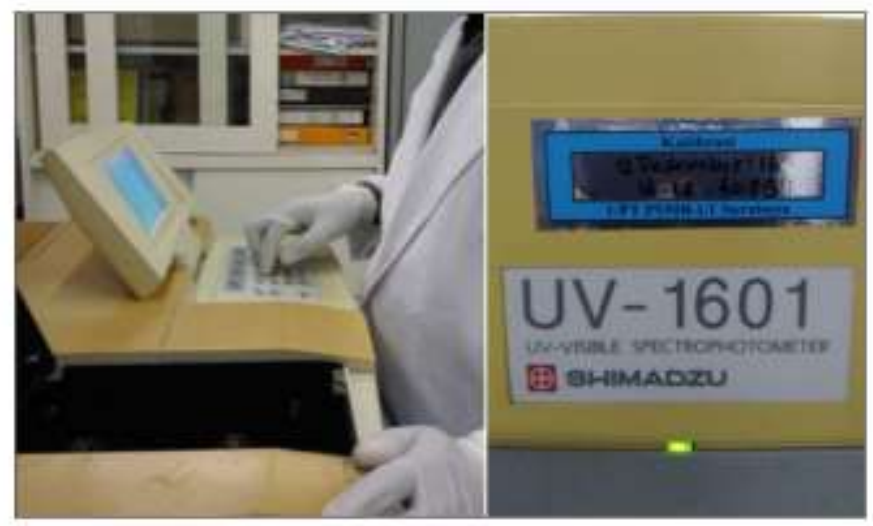

PCR machine used to polymerase targeted STR loci... thermal cycler

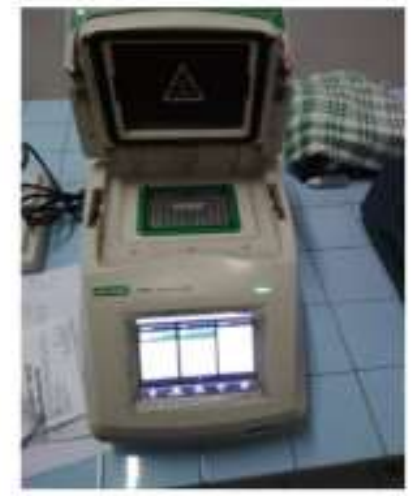

Electrophoretic reaction by the use of Vertical electrophoresis (acrylamide gel) to contrast AMEL gene

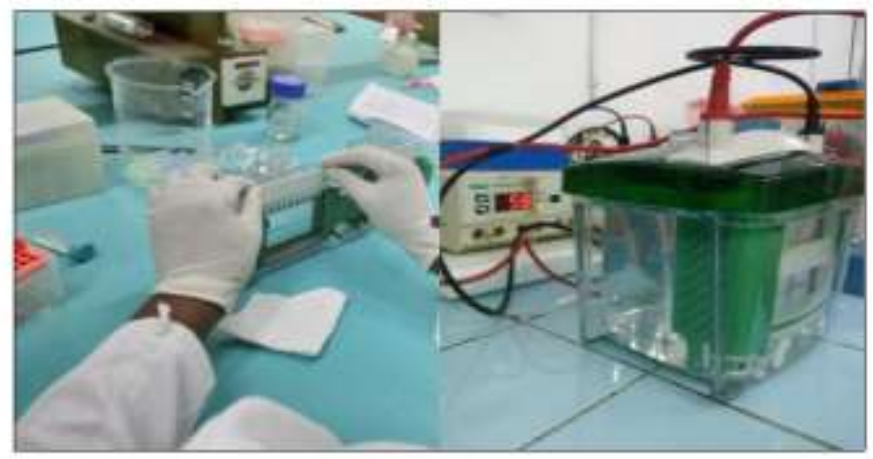

E: Toothbrushes used Colgate toothpaste used

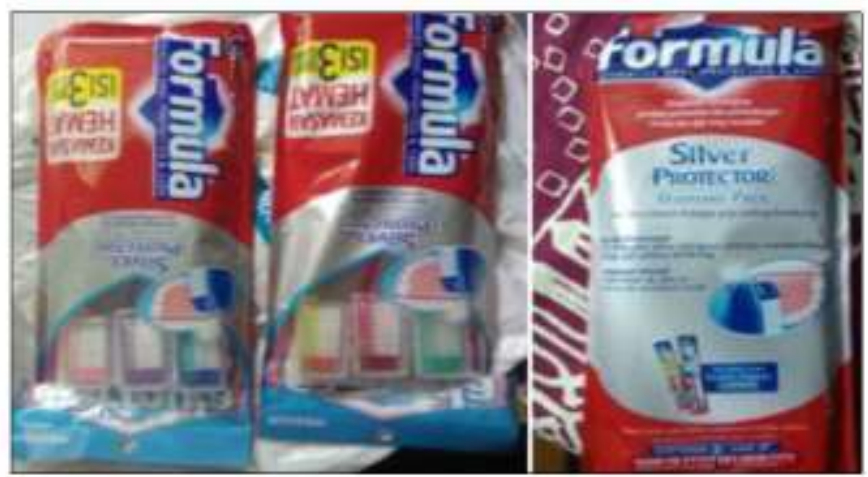




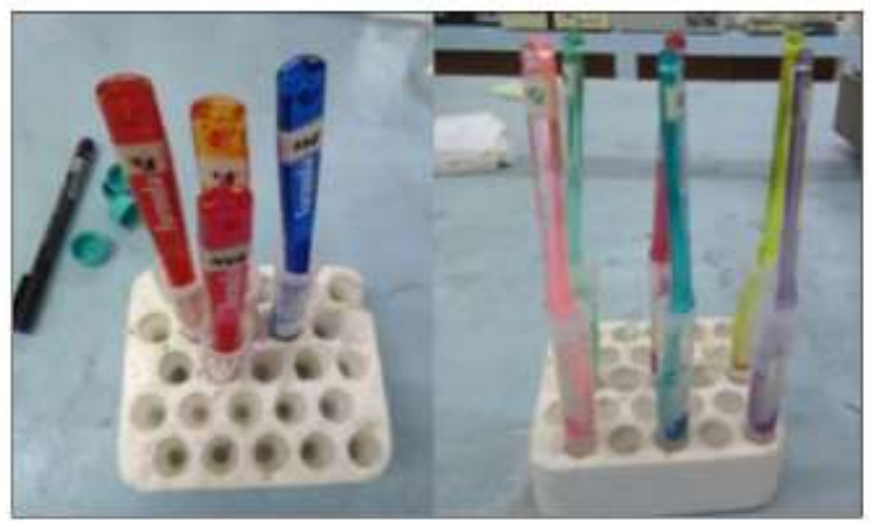

G: Centrifuge machine used
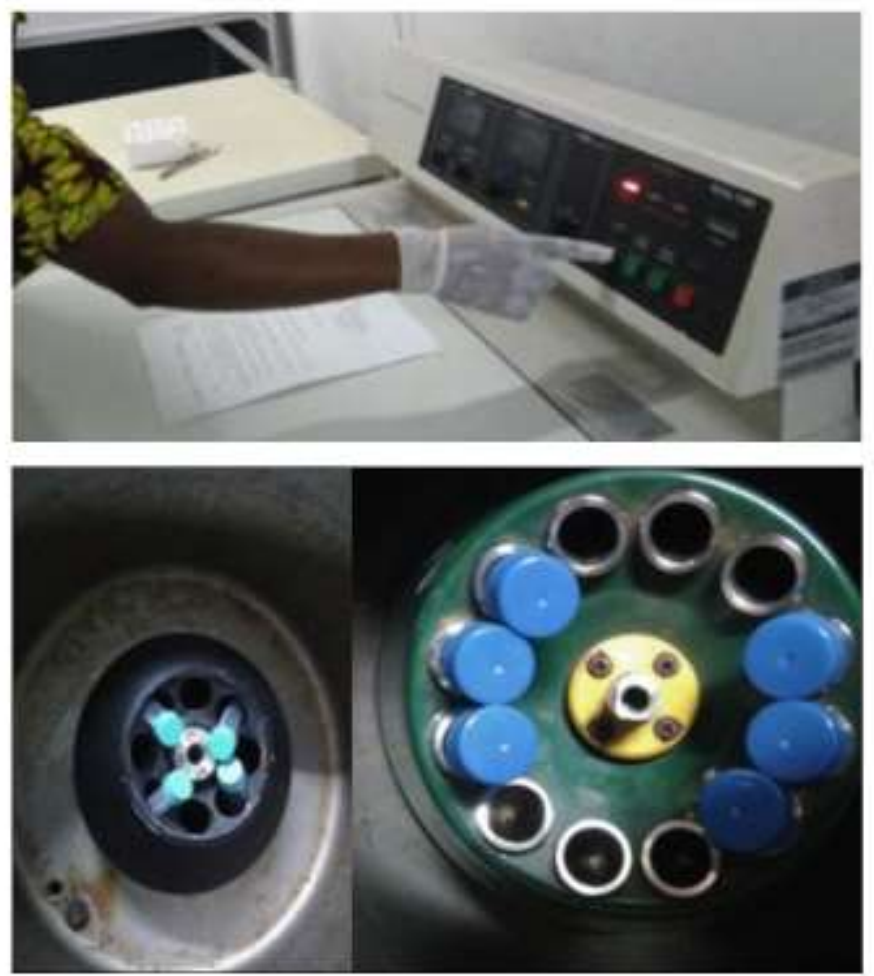

RESULTS :

Amel Gene profile sex detection :

The Polymerase Chain Reactions ( $\mathrm{P}$ C R ) through electrophoresis visualization of the profile identified correctly nine out of ten (Table 1).

Amelogenin gene detection presented two bands for male samples and one band for female samples (Figure 1). However one sample didn't respond to any of the sex gene categories during electrophoresis ionic segregation (no band appearance). Based upon it, participants were divided into three categories :
True positive male (M3 - M8) : Amelogenin identified by 106 and $112 \mathrm{bp}$ in reference to $100 \mathrm{bp}$

True positive female (F2, F9 \& F10) : Amelogenin identified by 106bp in reference to $100 \mathrm{bp}$

Null (F1) : no observed band presented on a profile

The null presenting sample (F1) category on further examination was found accumulated with green toothpaste remains of Sodium Monofluoro phosphate (Compound constituted in toothpaste) which is supported and proven to have contributory damage and degradation effect to DNA molecules ${ }^{[21-24]}$.

Table 1: Determined Sex by Amel Gene Profile of 106bp and 112bp DNA Band

\begin{tabular}{|l|l|l|}
\hline Sample code & Amel gene & Sample Sex \\
\hline F1 & Null ( - ) & Null ( - ) \\
\hline F2 & $106 \mathrm{bp}$ & Female \\
\hline M3 & $106 \mathrm{bp} \& 112 \mathrm{bp}$ & Male \\
\hline M4 & $106 \mathrm{bp} \mathrm{\&} \mathrm{112bp}$ & Male \\
\hline M5 & $106 \mathrm{bp} \mathrm{\&} \mathrm{112bp}$ & Male \\
\hline M6 & $106 \mathrm{bp} \mathrm{\&} \mathrm{112bp}$ & Male \\
\hline M7 & $106 \mathrm{bp} \mathrm{\&} \mathrm{112bp}$ & Male \\
\hline M8 & $106 \mathrm{bp} \mathrm{\&} \mathrm{112bp}$ & Male \\
\hline F9 & $106 \mathrm{bp}$ & Female \\
\hline F10 & $106 \mathrm{bp}$ & Female \\
\hline
\end{tabular}

Figure 1: Determined Male sex on M3 - M8, Female on F2, F9 \& F10 with the blank F1 sample with reference to Amel gene-sex determinants.

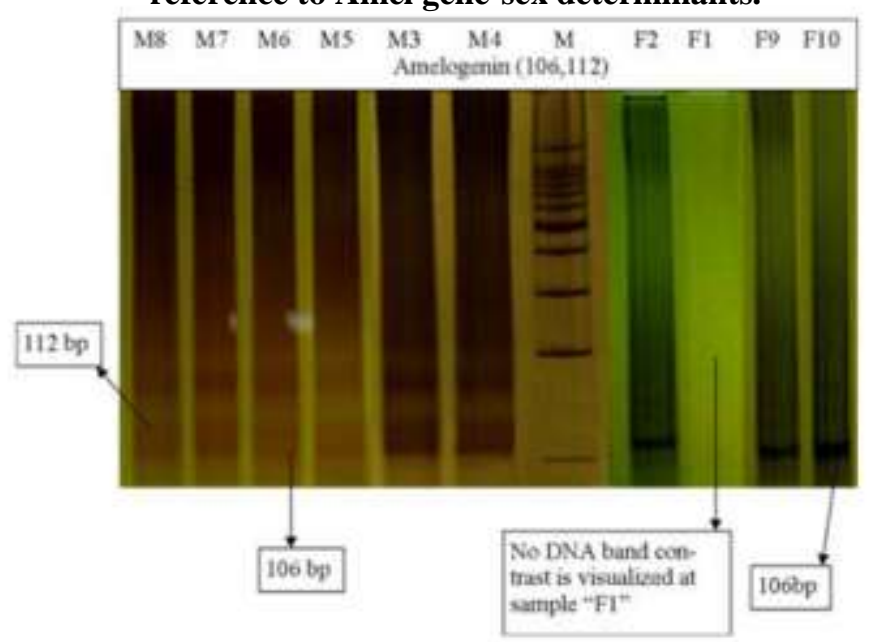

\section{DISCUSSION :}

Amelogenin gene is scientifically proved as a marker for sex determination. Present study has shown its applicability to Tanzania population which will help in solving forensic inquiries. Our findings are similar to studies by Indian authors $[8,13,14]$. The sample profiled from toothbrush logged cells successfully responded to the testing of Amelogenin as similar to study by Kashyap et al ${ }^{[10]}$. The finding is also supported by the fact that Amel profiling still work better except in 
destructive and inhibitory media (toothpaste in this case).

In this study, all toothbrushes used responded to amelogenin sex determination except one that presented an undetectable DNA band on the electrophoresis profile as portrayed in Figure1.

The undetectable sample implies and agrees with the effect of fluorine ingredient in the toothpaste as established by similar other studies ${ }^{[21-22]}$. Otherwise, the usage of toothbrush despite the predisposed and potential degradation, contaminants and inhibitory factors, remain reliable and preferred physical evidence at crime scene for recovering DNA samples. Toothbrush like many other sources of collecting evidence weighs similar importance and value in terms of usefulness, reliability, and applicability among Tanzanians.

\section{CONCLUSION :}

The toothbrush continue to be an important source to solve forensic inquiries especially related to identification and individualization. It has yielded enough quality DNA that successfully resulted in good DNA profiling. Amelogenin gene analysis has presented a convincing and promising finding for sex determination.

\section{REFERENCES :}

Souza DHD, Kiran J, Harish SS. Determination of Sex by Shape and Size of Hyoid Bone. J Indian Acad Forensic Med. 2013;35(2):145-7.

Roewer L. DNA fingerprinting in forensics: past, present, future. Investig Genet. 2013;4(1):22.

Jobim M.R, Gamio F, Ewald G, Jobim M, Jobim LF. Human identification using DNA purified from residues in used toothbrushes. Int Congr Ser. 2004;1261:491-3.

Reddy VS, Sriram G, Saraswathi T, Sivapathasundharam B. Isolation of epithelial cells from toothbrush and gender identification by amplification of SRY gene. J Forensic Dent Sci. 2011;3(1):27.

Riemer LB, Fairley D, Sweet D. DNA Collection From Used Toothbrushes as a Means to Decedent Identification. Am J Forensic Med Pathol. 2012;33(4):354-6.

Tanaka M, Yoshimoto T, Nozawa H, Ohtaki H, Kato Y, Sato $\mathrm{K}$, et al. Usefulness of a toothbrush as a source of evidential DNA for typing . J Forensic Sci . 2000 May [cited 2017 Aug 17];45(3):674-6.

Locard E . Locard's Exchange Principle - Forensic

HandbookForensic Handbook. 1910.

Ramakrishnan K, Sharma S, Sreeja C, Pratima DB, Aesha I, Vijayabanu B. Sex determination in forensic odontology: A review. J Pharm Bioallied Sci. 2015 Aug [cited 2017 Aug 17];7(Suppl 2):S398-402.

Haas-Rochholz H, Weiler G. Additional primer sets for an amelogenin gene PCR-based DNA-sex test. Int J Legal Med.
1997;110(6):312-5.

Kashyap VK, Sahoo S, Sitalaximi T, Trivedi R. Deletions in the Y-derived amelogenin gene fragment in the Indian population. BMC Med Genet. 2006;7:37.

Kao LG, Tsai LC, Lee JC, Hsieh HM. Controversial cases of human gender identification by amelogenin test. J Forenic Sci.2007;6(2):69-71.

Thangaraj K, Reddy AG, Singh L. Is the amelogenin gene reliable for gender identification in forensic casework and prenatal diagnosis? Int J Legal Med. 2002 ;116(2):121-3.

Sivagami A V., Rao AR, Varshney U. A simple and costeffective method for preparing DNA from the hard tooth tissue, and its use in polymerase chain reaction amplification of the amelogenin gene segment for sex determination in an Indian population. Forensic Sci Int. 2000;110(2):107-15.

Steinlechner M, Berger B, Niederstätter H, Parson W. Rare failures in the amelogenin sex test. Int $\mathrm{J}$ Legal Med. 2002;116(2):117-20.

Pretty IA, Sweet D. A look at forensic dentistry - Part 1: The role of teeth in the determination of human identity. Br Dent J. 2001;190(7):359-66.

Basnaker M, Moolrajani C. Determination of Sex by Dental Pulp Tissue - A Single Blind Study Bhavnagar University's Journal of Dentistry. 2016;6(1):1-6.

GCLA. Government Chemist Laboratory Act, Tanzania. 2016;

Chen H, Rangasamy M, Tan SY, Wang H, Siegfried BD. Evaluation of five methods for total DNA extraction from western corn rootworm beetles. PLoS One. 2010;5(8).

Chomczynski P, Mackey K, Drews R, Wilfinger W. DNAzol: A reagent for the rapid isolation of genomic DNA. Biotechniques. 1997;22(3):550-3.

Sullivan KM, Mannucci A, Kimpton CP, Gill P. A rapid and quantitative DNA sex test: fluorescence-based PCR analysis of X - Y homologous gene amelogenin. Biotechniques . 1993;15(4):636-8, 640-1.

Nzilibili SMM, Ekodiyanto MKH, Hardjanto P, Yudianto A. Concentration and Purity DNA Spectrophotometer: Sodium Monofluorophosphate forensic impended effect. Egypt $J$ Forensic Sci. 2018;8(1):34.

Yiamouyiannis J. Consumer Health Articles: fluoride, the silent killer. 1998

Adams SE, Arnold D, Murphy B, Carroll P, Green AK, Smith $\mathrm{AM}$, et al. A randomised clinical study to determine the effect of a toothpaste containing enzymes and proteins on plaque oral microbiome ecology. Sci Rep. 2017;7:43344.

Alfadaly N, Kassab A, Al Hedaithy F. Determination of DNA profiling of siwak and toothbrush samples used in Kingdom of Saudi Arabia. Egypt J Med Hum Genet. 2016;17(4):383-7.

Bandhaya A, Panvisavas N. Optimaization of DNA recovery from toothbrushes. Forensic Sci Int Genet Suppl Ser. 2008;1(1):9-10. 
